\title{
KARAKTERISASI BIODIESEL DARI MINYAK KEMIRI SUNAN DENGAN KATALIS HETEROGEN SILIKA TERIMPREGNASI KALSIUM OKSIDA $\left(\mathrm{CaO} / \mathrm{SiO}_{2}\right)$ (Characterization of Biodiesel Made from Kemiri Sunan Oil using Heterogeneous Silica Catalyst Impregnated by Calcium Oxide)
}

\author{
Haryono $^{1}$, Yati B. Yuliyati ${ }^{1}$, Atiek Rostika Noviyanti ${ }^{1}$, Mochammad Rizal ${ }^{1}$, \\ \& Sarifah Nurjanah ${ }^{2}$
}

\begin{abstract}
${ }^{1}$ Departemen Kimia, Fakultas Matematika dan Ilmu Pengetahuan Alam, Universitas Padjadjaran Jl. Raya Bandung-Sumedang Km. 21 Jatinangor 45363, Telp. (022) 7797712, Faks. (022) 7794545 ${ }^{2}$ Departemen Teknik Pertanian dan Biosistem, Fakultas Teknologi Industri Pertanian, Universitas Padjadjaran Jl. Raya Bandung-Sumedang KM. 21. Jatinangor 40800, Telp. (022) 7798844, Faks. (022) 7795780 E-mail : haryono@unpad.ac.id
\end{abstract}

Diterima 23 September 2019, direvisi 15 Oktober 2019, disetujui 18 Februari 2020

\begin{abstract}
Commercial biodiesel of oil palm is controversial as the palm oil is classified as food oil and palm plantation utilizes fertile land. One potential type of vegetable oil as biodiesel raw material is kemiri sunan Reutealis trisperma (Blanco) Airy Shaw) oil. This research aimed to prepare a heterogeneous solid catalyst in the form of an impregnated $\mathrm{SiO}_{2}$ by $\mathrm{CaO}$ catalyst $\left(\mathrm{CaO} / \mathrm{SiO}_{2}\right)$, to study the effect of the esterification stage on free fatty acid (FFA) content of oil, and to test the activity of the $\mathrm{CaO} / \mathrm{SiO}$ catalyst during the trans-esterification stage for biodiesel formation. $\mathrm{CaO} /$ $\mathrm{SiO}_{2}$ catalysts were prepared by sol-gel method made from natural materials (egg shells and rice husk). The FFA content of kemiri sunan oil was determined through various esterification stages namely 1; 1.5; and 2 hours in the presence of $\mathrm{H}_{2} \mathrm{SO}_{4}$ catalyst. While the trans-esterification stage was carried out under reaction temperature of $60^{\circ} \mathrm{C}$, oil to methanol ratio of 1:9, reaction time of 2 hours and $\mathrm{CaO} / \mathrm{SiO}_{2}$ catalyst content of 3\%. The results showed that the esterification stage for 1; 1.5; and 2 bours reduced the FFA content from 12.5\% (without esterification) to $0.65 \%$; $0.58 \%$; and $0.54 \%$ respectivaly. Biodiesel made from kemiri sunan oil which was synthesized with the addition of $\mathrm{CaO} / \mathrm{SiO}_{2}$ catalyst at optimal conditions of trans-esterification stage fulfilled SNI 7182-2015: Biodiesel based on density, viscocity, moisture content, iodine number, and cetane number.
\end{abstract}

Keywords: Biodiesel, free fatty acid content, heterogeneous catalyst, kemiri sunan oil, trans-esterification

\begin{abstract}
ABSTRAK
Biodiesel komersial umumnya diproduksi dari minyak sawit yang telah menjadi kontroversi karena minyak sawit merupakan minyak pangan dan tanaman kelapa sawit memanfaatkan lahan subur. Salah satu jenis minyak nabati potensial sebagai bahan baku pembuatan biodiesel adalah minyak kemiri sunan (Reutealis trisperma (Blanco) Airy Shaw). Minyak kemiri sunan bersifat non-pangan sehingga tidak akan berkompetisi dengan kebutuhan pangan. Dalam pembentukan biodiesel, penggunaan katalis basa homogen pada tahap trans-esterifikasi berpotensi menimbulkan beberapa masalah, salah satunya akibat keberadaan asam lemak bebas (ALB). Penelitian ini bertujuan menyiapkan katalis padat heterogen berupa katalis $\mathrm{SiO}_{2}$ terimpregnasi $\mathrm{CaO}\left(\mathrm{CaO} / \mathrm{SiO}_{2}\right)$, mempelajari pengaruh tahap esterifikasi terhadap perubahan kadar ALB minyak, dan menguji aktivitas katalis $\mathrm{CaO} / \mathrm{SiO}_{2}$ pada tahap trans-esterifikasi dalam pembentukan biodiesel. Katalis $\mathrm{CaO} / \mathrm{SiO}_{2}$ disiapkan dengan metode sol-gel dari bahan alam (cangkang telur dan sekam padi). Kadar ALB dari minyak kemiri sunan divariasikan melalui tahap esterifikasi selama 1; 1,5; dan 2 jam dengan bantuan katalis $\mathrm{H}_{2} \mathrm{SO}_{4}$, sedangkan tahap
\end{abstract}


trans-esterifikasi dilakukan pada suhu $60^{\circ} \mathrm{C}$, rasio mol minyak terhadap metanol sebesar 1:9, lama reaksi dua jam, dan kadar katalis $\mathrm{CaO} / \mathrm{SiO}_{2}$ sebanyak 3\%. Hasil penelitian menunjukkan bahwa tahap esterifikasi selama 1; 1,5; dan 2 jam telah mampu menurunkan kadar ALB minyak dari 12,5\% (tanpa esterifikasi) menjadi $0,65 \%$; $0,58 \%$; dan $0,54 \%$. Biodiesel dari minyak kemiri sunan yang disintesis dengan bantuan katalis $\mathrm{CaO} / \mathrm{SiO}_{2}$ pada kondisi optimal di tahap trans-esterifikasi memenuhi standar SNI 7182-2015 mengenai biodiesel, untuk parameter densitas, viskositas, kadar air, bilangan iodin, dan bilangan cetana.

Kata kunci : Biodiesel, kadar ALB, katalis heterogen, minyak kemiri sunan, trans-esterifikasi

\section{PENDAHULUAN}

Biodiesel merupakan bahan bakar alternatif potensial sebagai substitusi bahan bakar minyak (BBM) jenis minyak diesel. Namun demikian, biodiesel umumnya masih diproduksi dengan bahan baku minyak sawit. Hal tersebut telah menimbulkan permasalahan tersendiri karena minyak sawit merupakan minyak pangan dan pembudidayaannya dilakukan pada tanah atau lahan-lahan subur (Habibie \& Clarke, 2012). Pemakaian biodiesel pada mesin diesel memiliki banyak keuntungan. Murugesan, Umarani, Subramanian, dan Nedunchezhian (2009) menyatakan bahwa biodiesel memiliki bilangan setana yang tinggi, sifat pelumasan yang baik, dan dapat digunakan dengan sedikit atau tanpa modifikasi mesin, atau dengan pertimbangan tertentu dapat dicampur dengan minyak diesel.

Biodiesel dapat dibuat dari berbagai jenis minyak nabati dan lemak (Knothe, Gerpen, \& Krahl, 2005).Jenis minyak nabati potensial sebagai bahan baku pembuatan biodiesel adalah minyak dari biji tanaman kemiri sunan (Reutealis trisperma (Blanco) Airy Shaw). Minyak kemiri sunan bersifat non-pangan sehingga tidak berkompetisi dengan kebutuhan pangan dan harganya relatif lebih murah (Juan, Wu, \& Taufiq, 2011). Biji kemiri sunan memiliki kandungan minyak mencapai 45-55\% (Pranowo et al., 2013). Nurjanah et al. (2019) telah mempelajari pengaruh perubahan kapasitas produksi biodiesel dari minyak kemiri sunan pada tahap trans-esterifikasi dengan katalis homogen $\mathrm{KOH}$ terhadap rendemen, sifatsifat fisiko-kimia, dan komposisi asam lemak biodiesel.

Biodiesel dari minyak kemiri sunan juga telah disintesis dengan berbagai metode dan katalis. Pengaruh penggunaan pengaduk mekanik dan gelombang ultrasonik dengan katalis homogen $\mathrm{KOH}$ terhadap rendemen dan kualitas biodiesel dari minyak kemiri sunan telah dipelajari oleh Supriyadi, Purwanto, Anggoro, dan Hermawan (2018). Hendra (2014) telah mensintesis biodiesel dari minyak kemiri sunan dengan beberapa variasi jenis katalis homogen, baik pada tahap esterifikasi $\left(\mathrm{H}_{2} \mathrm{SO}_{4}\right.$ dan $\left.\mathrm{HCl}\right)$, maupun pada tahap trans-esterifikasi (KOH dan $\mathrm{NaOH}$ ). Pemrosesan biji kemiri sunan menjadi biodiesel dengan melibatkan katalis homogen $\mathrm{H}_{2} \mathrm{SO}_{4}$ dan $\mathrm{KOH}$ melalui studi pengaruh metode ekstraksi padat-cair pada tahap pengambilan minyak biji jarak, juga telah dilakukan oleh Djenar dan Lintang (2012).

Penggunaan katalis basa homogen pada tahap trans-esterifikasi dalam pembentukan biodiesel relatif berpotensimenimbulkanbeberapamasalah, seperti terjadinya reaksi penyabunan, peningkatan viskositas, ketidakoptimalan rendemen biodiesel, dan relatif sulitnya pemisahan katalis pada akhir reaksi (Mat, Samsudin, Mohamed, \& Johari, 2012). Oleh karena itu, pemakaian katalis basa heterogen dapat dipertimbangkan untuk mengurangi permasalahan-permasalahan tersebut. Kalsium oksida, $(\mathrm{CaO})$, telah mendapat banyak perhatian sebagai katalis heterogen padat untuk sintesis biodiesel karena membutuhkan kondisi reaksi yang ringan, relatif murah, dan kurang berdampak buruk terhadap lingkungan (Witoon, 2014).

Kalsium oksida tanpa modifikasi dari berbagai sumber telah disiapkan dengan karakteristik tertentu dan dimanfaatkan sebagai katalis heterogen pada sintesis biodiesel (Haryono, Natanael, Rukiah, \& Yuliyati, 2018; BankovićIlić, Miladinović, Stamenković, \& Veljković, 2017; Maneerung, Kawi, Dai, \& Wang, 2016; 
Reyero, Arzamendi, \& Gandía, 2014). Perbaikan karakteristik katalis heterogen padat dapat dilakukan dengan berbagai upaya. Salah satunya dengan memperluas permukaan spesifiknya dengan diimpregnasikan pada silika $\left(\mathrm{SiO}_{2}\right)$. Silika mesopori dari limbah pertanian memiliki kandungan $\mathrm{SiO}_{2}$ amorf tinggi (Ghorbani, Sanati, \& Maleki, 2015). Lani, Ngadi, Yahya, dan Rahman (2017) berhasil memperbaiki karakteristik katalis $\mathrm{CaO}$ melalui metode impregnasi dengan silika dari sekam padi. Katalis $\mathrm{CaO} / \mathrm{SiO}_{2}$ dengan karakteristik tertentu telah disintesis dari berbagai jenis limbah industri untuk dimanfaatkan sebagai katalis pada sintesis biodiesel (Yamaguchi et al., 2015).

Keoptimalan kinerja reaksi katalitik heterogen pada sintesis biodiesel dipengaruhi oleh karakteristik katalis, kondisi reaksi, dan sifat fisiko-kimia minyak. Sifat fisiko-kimia dari minyak nabati yang akan mempengaruhi kinerja reaksi katalitik, khususnya katalis heterogen padat, pada sintesis biodiesel adalah kadar asam lemak bebas (ALB) dari minyak nabati sebagai bahan baku (Le \& Jeong, 2014; Yan, Kim, Salley, \& Simon, 2009). Penelitian ini bertujuan menyiapkan katalis padat heterogen $\mathrm{CaO} / \mathrm{SiO}_{2}$, mempelajari pengaruh tahap esterifikasi terhadap perubahan kadar ALB minyak, dan menguji aktivitas katalis $\mathrm{CaO} / \mathrm{SiO}_{2}$ pada tahap trans-esterifikasi dalam pembentukan biodiesel.

\section{BAHAN DAN METODE}

Penelitian dilakukan di Laboratorium Kimia Fisik dan Anorganik, Departemen Kimia, FMIPA, Universitas Padjadjaran. Prosedur eksperimen meliputi: preparasi (degumming) dan analisis minyak kemiri sunan, esterifikasi minyak kemiri sunan, preparasi dan karakterisasi katalis $\mathrm{CaO} / \mathrm{SiO}_{2}$, penentuan kadar asam lemak bebas dari minyak hasil esterifikasi, trans-esterifikasi minyak kemiri sunan menjadi biodiesel, dan karakterisasi biodiesel. Pada penelitian ini, katalis $\mathrm{CaO} / \mathrm{SiO}_{2}$ disiapkan dari bahan limbah berupa cangkang telur ayam sebagai bahan baku $\mathrm{CaO}$, dan sekam padi sebagai sumber $\mathrm{SiO}_{2}$. Bahan limbah tersebut diperoleh dari daerah Jatinangor (Sumedang) dan sekitarnya. Minyak kemiri sunan mentah (crude) diperoleh dari daerah Wanaraja, Kabupaten Garut.
Minyak kemiri sunan kasar (crude), sebelum diesterifikasi, dimurnikan terlebih dahulu dengan metode degumming dengan menambahkan larutan $\mathrm{H}_{3} \mathrm{PO}_{4} 85 \%$ sebanyak $0,09 \%$ b/b ke dalam minyak kemiri sunan pada suhu $80^{\circ} \mathrm{C}$ sambil diaduk. Setelah dua menit, larutan $\mathrm{NaOH} 0,5 \mathrm{~N}$ sebanyak 3,26\% terhadap minyak ditambahkan ke dalam campuran minyak, kemudian dipanaskan sambil diaduk pada suhu $80^{\circ} \mathrm{C}$ selama 30 menit. Campuran disentrifugasi pada kecepatan 1800 rpm selama 10 menit untuk memisahkan air dan gum dari fase minyak. Minyak kemiri sunan dari tahap degumming kemudian dianalisis sifat fisikokimianya berdasarkan parameter uji densitas, viskositas, bilangan asam, kadar air berdasarkan SNI 7182, (2015), dan warna menggunakan kromatometer.

Kalsium oksida sebagai bagian aktif dari katalis disiapkan dari cangkang telur. Cangkang telur digerus dan diayak untuk diperoleh serbuk berukuran lolos 100 mesh. Serbuk cangkang telur kemudian dikalsinasi pada suhu $1000^{\circ} \mathrm{C}$ di tekanan atmosfer selama lima jam dengan laju pemanasan $10^{\circ} \mathrm{C} /$ menit. Selanjutnya hasil kalsinasi berupa serbuk $\mathrm{CaO}$ berwarna putih dikarakterisasi dengan spektrometer. Untuk $\mathrm{SiO}_{2}$ sebagai material pendukung katalis disiapkan dari sekam padi melalui tahapan: pemisahan oksida logam pengotor secara ekstraksi dengan pelarut $\mathrm{HCl} 37 \% 1 \mathrm{~N}$, pengabuan pada suhu $600^{\circ} \mathrm{C}$, pembentukan $\mathrm{Na}_{2} \mathrm{SiO}_{3}$ dengan pereaksian menggunakan larutan $\mathrm{NaOH} 0,5 \mathrm{M}$ pada rasio abu terhadap $\mathrm{NaOH}$ sebesar 1:100 (b/v) pada suhu $100^{\circ} \mathrm{C}$, dan pembentukan $\mathrm{SiO}_{2}$ gel dengan bantuan $\mathrm{H}_{2} \mathrm{SO}_{4} 10 \%$. Silika yang dihasilkan kemudian dikarakterisasi dengan metode spektroskopi X-Ray Fluorecence (Lani, Ngadi, Yahya, \& Rahman, 2017).

Katalis $\mathrm{SiO}_{2}$ terimpregnasi $\mathrm{CaO} \quad(\mathrm{CaO} /$ $\mathrm{SiO}_{2}$ ) disiapkan dengan metode impregnasi basah. Kalsium oksida dilarutkan ke dalam akuades sehingga diperoleh larutan $\mathrm{CaO}$ dengan konsentrasi 5\% (b/v). Selanjutnya serbuk $\mathrm{SiO}_{2}$ sebanyak 3\% dicampurkan ke dalam larutan $\mathrm{CaO}$. Campuran direfluks pada suhu $80^{\circ} \mathrm{C}$ selama empat jam. Setelah dilakukan penyaringan, residu (hasil padat) dikeringkan di dalam oven pada suhu $60^{\circ} \mathrm{C}$ selama 24 jam. Pada tahap terakhir, katalis dikalsinasi pada suhu $800^{\circ} \mathrm{C}$ selama tiga 
jam, didinginkan, dan dikarakterisasi dengan metode X-Ray Diffraction, X-Ray Fluorecence, adsorpsi Brunauer-Emmett-Teller (Lani, Ngadi, Yahya, \& Rahman, 2017), dan ditentukan densitas kebasaannya dengan titrasi asam-basa (Kim, Salley, \& Simon, 2008).

Pada tahap sintesis biodiesel dengan katalis $\mathrm{SiO}_{2}$ terimpregnasi $\mathrm{CaO}\left(\mathrm{CaO} / \mathrm{SiO}_{2}\right)$ yang telah disiapkan, sintesis dilakukan dalam dua tahap, yaitu: tahap esterifikasi (divariasikan waktunya pada 1,$0 ; 1,5$; dan 2,0 jam) dan tahap transesterifikasi. Pada tahap trans-esterifikasi, selain digunakan minyak kemiri sunan dari hasil tahap esterifikasi, sebagai bahan baku juga digunakan minyak kemiri sunan tanpa esterifikasi. Esterifikasi dilakukan dalam reaktor batch. Sebanyak $100 \mathrm{ml}$ minyak kemiri sunan direaksikan dengan metanol (99,9\%, Merck) dan dibantu $\mathrm{H}_{2} \mathrm{SO}_{4}$ pekat (Merck, 95-97\%) sebagai katalis. Esterifikasi dilakukan pada rasio mol minyak terhadap metanol 1:6, kadar katalis $1 \% \mathrm{v}$, suhu $60^{\circ} \mathrm{C}$, dan kecepatan pengadukan $500 \mathrm{rpm}$. Hasil esterifikasi kemudian dicuci dengan akuades panas sampai $\mathrm{pH}$ netral. Setelah dilakukan penguapan air dan metanol sisa, hasil esterifikasi kemudian direaksikan menjadi biodiesel pada tahap trans-esterifikasi.

Pada tahap trans-esterifikasi, sebanyak $100 \mathrm{ml}$ minyak hasil esterifikasi dari setiap variasi waktu reaksi (dan tanpa esterifikasi) direaksikan dengan metanol pada rasio mol minyak terhadap metanol sebesar 1:9. Reaksi dibantu katalis $\mathrm{CaO} / \mathrm{SiO}_{2}$ yang telah disiapkan dengan kadar katalis 3\%. Reaksi trans-esterifikasi tersebut dilakukan pada suhu $60^{\circ} \mathrm{C}$ selama dua jam. Hasil reaksi trans- esterifikasi diperoleh dalam bentuk campuran tiga lapisan. Biodiesel dipisahkan dari gliserol, metanol sisa, dan katalis sisa dengan sedimentasi, distilasi, dan sentrifugasi. Biodesel dari hasil pemurnian selanjutnya ditentukan rendemen dan dianalisis sifat fisikokimia (densitas dan viskositas) untuk menentukan kadar asam lemak bebas optimal dari minyak umpan (precursor) pada tahap trans-esterifikasi. Biodiesel dari kondisi optimum pada tahap trans-esterifikasi selanjutnya dianalisis bilangan asam, bilangan iodin, bilangan cetana, kadar air, dan komposisi metil ester. Mutu biodiesel hasil sintesis ditentukan berdasarkan SNI 7182-2015 (2015).

\section{HASIL DAN PEMBAHASAN}

Analisis minyak kemiri sunan bertujuan untuk mengetahui kondisi awal dari minyak kemiri sunan sebagai bahan baku pada pembuatan biodiesel. Hasil analisis ditampilkan pada Tabel 1.

Nilai densitas dan viskositas minyak nabati atau lemak merepresentasikan jenis dan komposisi asam lemak penyusun dari minyak atau lemak. Densitas minyak dipengaruhi oleh jumlah (persentase) ikatan rangkap dua dari asam lemak tak jenuh penyusun minyak. Minyak yang mengandung asam lemak tak jenuh dengan ikatan karbon rangkap dua (double bond) sejumlah lebih dari dua ikatan per molekul sebanyak lebih dari $25 \%$ menunjukkan keterkaitan dengan peningkatan densitas minyak. Viskositas minyak berhubungan dengan panjang pendek dan jumlah ikatan rangkap pada rantai karbon dari asam lemak

\section{Tabel 1. Sifat fisiko-kimia minyak kemiri sunan kasar}

\section{Table 1. Physico-chemical properties of kemiri sunan crude oil}

\begin{tabular}{clcc}
\hline No. & \multicolumn{1}{c}{$\begin{array}{c}\text { Parameter } \\
\text { (Parameters) }\end{array}$} & $\begin{array}{c}\text { Satuan } \\
(\text { Unit })\end{array}$ & $\begin{array}{c}\text { Nilai } \\
\text { (Value })\end{array}$ \\
\hline 1. & Densitas pada $40^{\circ} \mathrm{C}\left(\right.$ Density at $\left.40^{\circ} \mathrm{C}\right)$ & $\mathrm{kg} / \mathrm{m}^{3}$ & 930 \\
2. & Viskositas pada $40^{\circ} \mathrm{C}$ (Viscosity at $\left.40^{\circ} \mathrm{C}\right)$ & $\mathrm{mm}^{2} / \mathrm{s}(\mathrm{cSt})$ & 21,19 \\
3. & Bilangan asam $($ Acid number $)$ & $\mathrm{mg} \mathrm{KOH} / \mathrm{g}$ & 25,25 \\
4. & Kadar asam lemak bebas $(\mathrm{FFA}$ content $)$ & $\%$ & 12,50 \\
5. & Kadar air (Moisture content $)$ & $\%$ & 0,51 \\
6. & Warna (Colour) & ${ }^{\circ} \mathrm{HUE}$ & $\left.86,71^{\mathrm{a}}\right)$ \\
7. & Berat molekul rata-rata (Average molecular weight) & $\mathrm{g} / \mathrm{mol}$ & $858,94^{\mathrm{b})}$ \\
\hline
\end{tabular}

Keterangan (Remarks): ${ }^{\text {a) }} 86,71{ }^{\circ} \mathrm{HUE}=$ warna minyak kuning kemerahan $\left(86.71{ }^{\circ} \mathrm{HUE}=\right.$ reddish yellow oil colour $)$; ${ }^{\text {b }}$ Diperoleh dari komposisi asam lemak, kadar ALB, dan kadar trigliserida (Obtained from fatty acid composition, FFA and triglyceride content) 
penyusun minyak. Semakin pendek rantai karbon dan/ semakin banyak ikatan rangkap, viskositas minyak akan semakin kecil (Sanford, White, \& Shah, 2009; Knothe et al., 2005). Kramadibrata et al. (2017) melaporkan bahwa minyak kemiri sunan tersusun dari asam-asam lemak berupa: asam stearat (C18:0) 9\%, asam palmitat (C16:0) $10 \%$, asam oleat (C18:1) 12\%, asam linoeat (C18:2) 19\%, dan asam $\alpha$-oleostearat (C18:3) $50 \%$. Minyak inti sawit didominasi oleh asam lemak rantai pendek jenuh, yaitu asam laurat (C12:0) 47,8\%, asam miristat (C14:0) 16,3\%, dan asam oleat (C18:1) 15,4\% (Mancini et al., 2015). Hasil penelitian tersebut menunjukkan bahwa densitas dan viskositas minyak kemiri sunan cenderung lebih tinggi dibandingkan minyak inti sawit. Sebagai bahan baku biodiesel, jenis dan komposisi asam lemak tersebut mengakibatkan mutu minyak kemiri sunan relatif lebih baik dibandingkan minyak inti sawit dalam hal dampaknya terhadap nilai titik kabut, cold filter plugging point (CFPP), dan bilangan cetana dari biodiesel yang dihasilkan. Titik kabut dan CFPP menunjukkan kinerja biodiesel pada operasional mesin di suhu rendah. Namun mutu biodiesel dari minyak inti sawit memiliki keunggulan dalam hal ketahanan oksidasi (Sanford et al., 2009).
Kadar ALB minyak kemiri sunan berdasarkan Tabel 1 diperoleh sebesar 12,50\% (atau setara dengan bilangan asam sebesar 25,25 $\mathrm{mg} \mathrm{KOH} / \mathrm{g}$ minyak). Minyak nabati sebagai bahan baku pembuatan biodiesel, terutama dengan katalis basa homogen pada tahap trans-esterifikasi, menuntut kadar ALB rendah, yaitu $<0,5 \%$. Penggunaan minyak dengan kadar ALB tinggi menyebabkan terjadinya reaksi penyabunan sehingga, berdampak pada penurunan rendemen dan sulitnya pemurnian biodiesel (Mat et al., 2012).

Rendemen $\mathrm{CaO}$ dan $\mathrm{SiO}_{2}$ dari tahap penyiapan prekursor katalis serta hasil karakterisasi dengan XRF ditampilkan pada Tabel 2 yang menunjukkan bahwa $\mathrm{CaO}$ dan $\mathrm{SiO}_{2}$ dijumpai dalam kadar dominan pada masing-masing campurannya dengan berbagai oksida logam lainnya sebagai pengotor. Kadar $\mathrm{CaO}$ dalam hasil kalsinasi cangkang telur sebesar 97,8\%, sedangkan pada tahap penyiapan $\mathrm{SiO}_{2}$ diperoleh hasil dengan kadar $\mathrm{SiO}_{2}$ sebesar 86,3\%. Hasil penelitian tersebut relatif sama dibandingkan penelitian lain. Hasil kalsinasi dengan kadar $\mathrm{CaO}$ sebesar 99,06\% diperoleh dari kalsinasi cangkang telur bebek pada suhu $900^{\circ} \mathrm{C}$ selama satu jam (Tangboriboon, Kunanuruksapong, \& Sirivat,

Tabel 2. Rendemen dan hasil karakterisasi dengan $X$-Ray Fluorecence dari tahap penyiapan prekursor katalis pada pembuatan biodiesel dari minyak kemiri sunan

Table 2. Yield and characterization of catalyst precursors preparation tested XRF in biodiesel manufacturing from kemiri sunan oil

\begin{tabular}{|c|c|c|c|c|}
\hline \multirow{2}{*}{$\begin{array}{l}\text { Oksida logam } \\
\text { (Metal oxide) }\end{array}$} & \multicolumn{2}{|c|}{$\begin{array}{c}\text { Komposisi } \\
\text { (Composition, \%) }\end{array}$} & \multicolumn{2}{|c|}{$\begin{array}{l}\text { Rendemen } \\
\text { (Yield, \%) }\end{array}$} \\
\hline & $\begin{array}{l}\text { Penyiapan } \mathrm{CaO}^{1)} \\
(\mathrm{CaO} \text { preparation })\end{array}$ & $\begin{array}{l}\text { Penyiapan } \mathrm{SiO}_{2}^{2)} \\
\left(\mathrm{SiO}_{2} \text { preparation }\right)\end{array}$ & $\begin{array}{l}\text { Penyiapan } \mathrm{CaO}^{1)} \\
(\mathrm{CaO} \text { preparation })\end{array}$ & $\begin{array}{l}\text { Penyiapan } \mathrm{SiO}_{2}{ }_{2}^{2)} \\
\left(\mathrm{SiO}_{2} \text { preparation }\right)\end{array}$ \\
\hline $\mathrm{CaO}$ & 97,8 & - & & \\
\hline $\mathrm{SiO}_{2}$ & 0,157 & 86,3 & & \\
\hline $\mathrm{MgO}$ & 1,17 & - & & \\
\hline $\mathrm{Fe}_{2} \mathrm{O}_{3}$ & 0,0027 & 0,0085 & & \\
\hline $\mathrm{Al}_{2} \mathrm{O}_{3}$ & 0,189 & 0,53 & & \\
\hline $\mathrm{CuO}$ & 0,0012 & 0,0016 & $55,69 \pm 0,94$ & $95,85 \pm 3,93$ \\
\hline $\mathrm{K}_{2} \mathrm{O}$ & 0,193 & - & & \\
\hline $\mathrm{SO}_{3}$ & 0,208 & 3,35 & & \\
\hline $\mathrm{P}_{2} \mathrm{O}_{5}$ & 0,292 & - & & \\
\hline $\mathrm{ZnO}$ & - & 0,0036 & & \\
\hline $\mathrm{Na}_{2} \mathrm{O}$ & - & 9,78 & & \\
\hline
\end{tabular}

Keterangan (Remarks): ${ }^{1)}$ Penyiapan dengan dekomposisi termal cangkang telur (Preparation by thermal decomposition of the egg sheld; ${ }^{2)}$ Penyiapan dengan metode sol-gel terhadap abu sekam padi (Preparation by sol-gel method on rice busk ash) 


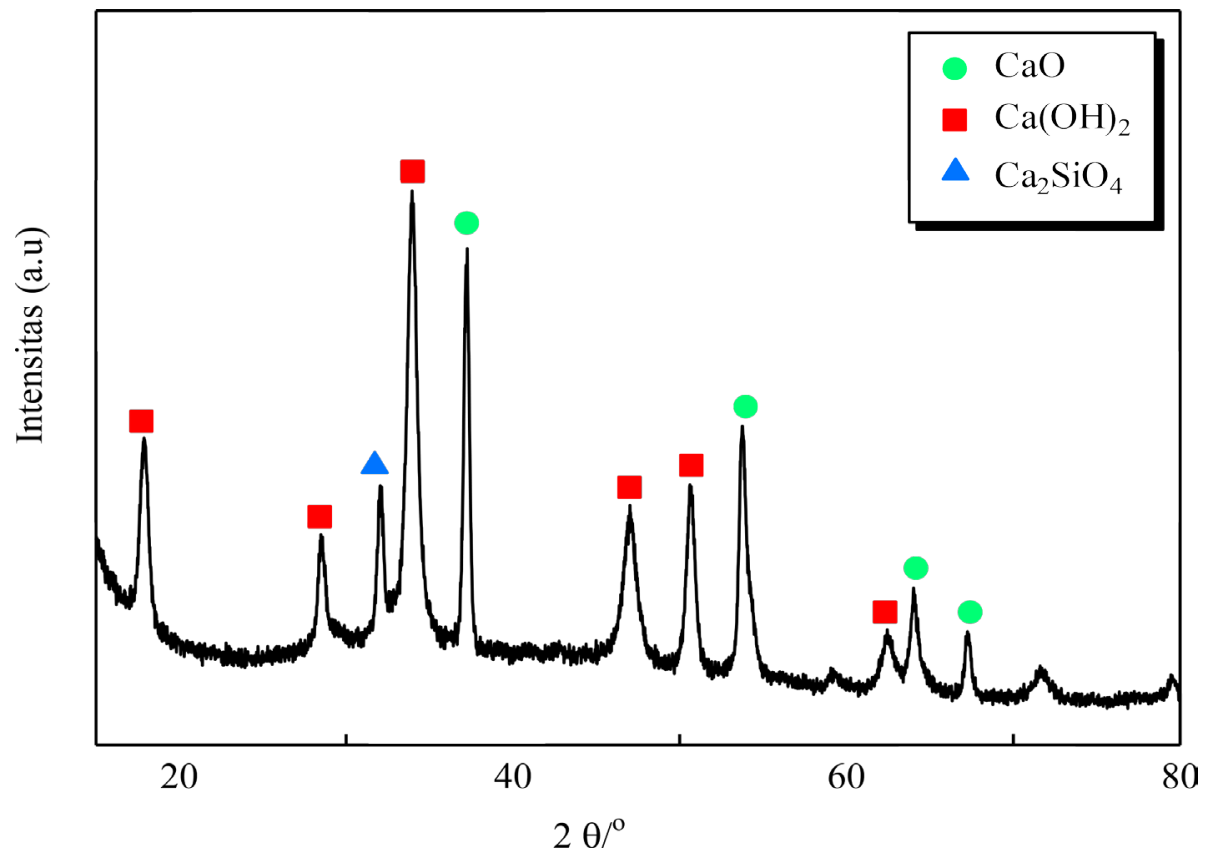

Gambar 1. Pola X-Ray Diffraction katalis $\mathrm{SiO}_{2}$ terimpregnasi $\mathrm{CaO}$ dari hasil kalsinasi pada suhu $800^{\circ} \mathrm{C}$ sebagai katalis pada pembuatan biodiesel dari minyak kemiri sunan

Figure 1. XRD pattern of the $\mathrm{SiO}_{2}$ catalyst impregnated by $\mathrm{CaO}$ from calcination at $800^{\circ} \mathrm{C}$ as catalyst in biodiesel manufacturing from kemiri sunan oil

2012). Ghorbani et al. (2015) memperoleh silika dari abu sekam padi dengan kadar $\mathrm{SiO}_{2}$ sebesar $85,15-92,89 \%$, tergantung pada metode yang digunakan.

Pada dekomposisi termal $\mathrm{CaCO}_{3}$ dari cangkang telur, selain dihasilkan $\mathrm{CaO}$ juga dihasilkan gas $\mathrm{CO}_{2}$ menurut Persamaan (1). Secara stoikiometris, dengan mengasumsikan cangkang telur hanya berupa $\mathrm{CaCO}_{3}$, dekomposisi termal tersebut akan menghasilkan $\mathrm{CaO}$ dengan rendemen 56\%. Hal ini menunjukkan bahwa tahap dekomposisi termal berlangsung mendekati stoikiometris, dan mengindikasikan kandungan pengotor (selain $\mathrm{CaCO}_{3}$ ) pada cangkang telur sangat sedikit. Pernyataan ini terkonfirmasi dari hasil karakterisasi dengan XRF terhadap campuran hasil dekomposisi termal cangkang telur (Tabel 2).

$\mathrm{CaCO}_{3}(s) \rightarrow \mathrm{CaO}(s)+\mathrm{CO}_{2}(g)$

$2 \mathrm{CaO}(s)+\mathrm{SiO}_{2}(s) \rightarrow \mathrm{Ca}_{2} \mathrm{SiO}_{4}(s)$

Penyiapan $\mathrm{SiO}_{2}$ dari abu sekam padi dengan metode sol-gel diperoleh hasil dengan rendemen sekitar 95,85\%. Sesuai hasil karakterisasi dengan XRF (Tabel 2), diperoleh hasil tingkat kemurnian $\mathrm{SiO}_{2}$ sebesar 86,3\%. Pada penelitian ini $\mathrm{SiO}_{2}$ disiapkan dengan metode sol-gel. Metode solgel merupakan metode pembentukan senyawa anorganik melalui reaksi kimia dalam larutan pada suhu rendah untuk mendapatkan ukuran partikel berukuran nano. Rasio molar antara pereaksi terhadap abu sekam padi akan memengaruhi ukuran serta distribusi partikel pada tahap pertumbuhan $\mathrm{SiO}_{2}$ (Le \& Jeong, 2014).

Modifikasi $\mathrm{CaO}$ dengan penyangga $\mathrm{SiO}_{2}$ menggunakan metode impregnasi bertujuan untuk meningkatkan kinerja $\mathrm{CaO}$ sebagai katalis. Impregnasi bertujuan mengisi bagian pori penyangga $\mathrm{SiO}_{2}$ dengan fase aktif $\mathrm{CaO}$. Katalis $\mathrm{CaO} / \mathrm{SiO}_{2}$ dari hasil impregnasi memiliki karakteristik tertentu. Gambar 1 menampilkan difraktogram katalis $\mathrm{CaO} / \mathrm{SiO}_{2}$ dari hasil karakterisasi dengan XRD. Puncak difraksi khas $\mathrm{CaO}$ dapat diamati pada $2 \theta$, yaitu di $37,19^{\circ} ; 53,7^{\circ}$; $64^{\circ}$, dan $67,22^{\circ}$. Puncak lain dengan intensitas cukup tinggi dijumpai pada $2 \theta$ sebesar $32,04^{\circ}$. Puncak tersebut menunjukkan terbentuknya fase baru berupa $\mathrm{Ca}_{2} \mathrm{SiO}_{4}$ (dikalsium silikat) berdasarkan Persamaan (2). Dikalsium silikat memiliki beberapa bentuk tipe kristal. Puncak kristal $\mathrm{Ca}_{2} \mathrm{SiO}_{4}$ dengan tipe kristal monoklinik berada pada rentang 20 32-33 ${ }^{\circ}$ (Yamaguchi et al., 2015). Puncak-puncak lainnya dijumpai pada 
$2 \theta 17,88^{\circ} ; 28,5^{\circ} ; 33,04^{\circ} ; 46,95^{\circ}$; dan $50,62^{\circ}$. Puncak-puncak tersebut merupakan puncak dari $\mathrm{Ca}(\mathrm{OH})_{2}$. Loy et al. (2016) menyatakan bahwa $\mathrm{Ca}(\mathrm{OH})_{2}$ terbentuk akibat terjadinya kontak antara permukaan $\mathrm{CaO}$ dengan uap air di udara. Terdapat kemungkinan adanya kontak antara $\mathrm{CaO}$ yang telah diimpregnasikan pada $\mathrm{SiO}_{2}$ dengan uap air saat proses penurunan suhu setelah dekomposisi termal, dari suhu $600^{\circ} \mathrm{C}$ hingga suhu ruang. $\mathrm{CaO}$ memiliki kekuatan adsorpsi kimia yang tinggi terhadap $\mathrm{H}_{2} \mathrm{O}$ membentuk $\mathrm{Ca}(\mathrm{OH})_{2}$.

Paramater katalis $\mathrm{CaO} / \mathrm{SiO}_{2}$ lainnya yang dikarakterisasiadalahkomposisioksidalogampada katalis dengan XRF (Tabel 3), luas permukaan, distribusi ukuran pori, dan densitas kebasaan (Tabel 4). Tahap impregnasi $\mathrm{CaO}$ ke permukaan penyangga berupa $\mathrm{SiO}_{2}$ pada penyiapan katalis $\mathrm{CaO} / \mathrm{SiO}_{2}$ dihasilkan katalis dengan kadar $\mathrm{CaO}$ dan $\mathrm{SiO}_{2}$ secara berturut-turut sebesar 95,5\% dan 2,35\% (Tabel 3). Nilai kadar $\mathrm{CaO}$ dan $\mathrm{SiO}_{2}$ pada katalis tersebut dipengaruhi oleh beberapa faktor, seperti: kemurnian prekursor $\mathrm{CaO}$ dan $\mathrm{SiO}_{2}$, rasio antar prekursor yang digunakan, tingkat keberhasilan tahap pelarutan $\mathrm{CaO}$, dan tingkat keberhasilan tahap impregnasi. Modifikasi katalis $\mathrm{CaO}$ menggunakan penyangga $\mathrm{SiO}_{2}$ berdampak pada perbaikan sifat fisis permukaan katalis, yaitu berupa peningkatan luas permukaan spesifik, serta diameter pori dan volume pori spesifik yang lebih variatif. Hal ini didasarkan pada perbandingan antara hasil penelitian ini dengan hasil penelitian kami sebelumnya (Haryono, Natanael, Rukiah, \& Yuliyati, 2018).
Perbaikan sifat-sifat fisis permukaan katalis tersebut umumnya akan meningkatkan konsentrasi sisi aktif permukaan katalis, sehingga interaksi antara reaktan dan katalis menjadi lebih intensif (Lani, Ngadi, Yahya, \& Rahman, 2017). Perbandingan hasil penelitian penyiapan katalis berbasis $\mathrm{CaO}$ sebagai petunjuk perubahan sifatsifat fisis permukaan katalis ditampilkan pada Tabel 4. Nampak bahwa katalis $\mathrm{CaO}$ dengan sumber, penyiapan, dan pemodifikasian berbeda berdampak terhadap perbedaan karakteristik permukaan $\mathrm{CaO}$ tersebut. Pemodifikasian $\mathrm{CaO}$ dengan penyangga $\mathrm{SiO}_{2}$ melalui metode impregnasi telah terbukti memperbaiki karakteristik permukaan $\mathrm{CaO}$ (Lani, Ngadi, Yahya, \& Rahman, 2017), begitu juga pada penelitian ini. Namun $\mathrm{CaO}$ tanpa diimpregnasikan pada $\mathrm{SiO}_{2}$ dimungkinkan memiliki luas permukaan spesifik lebih besar, jika terhadap $\mathrm{CaO}$ hasil dekomposisi termal dilakukan pengecilan lanjut (Haryono, Natanael, Rukiah, \& Yuliyati, 2018).

Perbaikan sifat-sifat fisis permukaan katalis tersebut umumnya akan meningkatkan konsentrasi sisi aktif permukaan katalis, sehingga interaksi antara reaktan dan katalis menjadi lebih intensif (Lani, Ngadi, Yahya, \& Rahman, 2017). Perbandingan hasil penelitian penyiapan katalis berbasis $\mathrm{CaO}$ sebagai petunjuk perubahan sifatsifat fisis permukaan katalis ditampilkan pada Tabel 4. Nampak bahwa katalis $\mathrm{CaO}$ dengan sumber, penyiapan, dan pemodifikasian berbeda berdampak terhadap perbedaan karakteristik permukaan $\mathrm{CaO}$ tersebut. Modifikasi CaOdengan

Tabel 3. Komposisi oksida logam katalis $\mathrm{CaO} / \mathrm{SiO}_{2}$ pada pembuatan biodiesel dari minyak kemiri sunan

Table 3. Metal oxide composition of the $\mathrm{CaO} / \mathrm{SiO}_{2}$ catalyst in biodiesel manufacturing from kemiri sunan oil

\begin{tabular}{cc}
\hline $\begin{array}{c}\text { Oksida logam } \\
(\text { Metal oxide })\end{array}$ & $\begin{array}{c}\text { Komposisi } \\
\text { (Composition, \%) }\end{array}$ \\
\hline $\mathrm{CaO}$ & 95,5 \\
$\mathrm{SiO}_{2}$ & 2,35 \\
$\mathrm{MgO}_{2}$ & 1,18 \\
$\mathrm{Fe}_{2}$ & 0,0262 \\
$\mathrm{Al}_{2} \mathrm{O}_{3}$ & 0,335 \\
$\mathrm{CuO}_{2}$ & 0,0073 \\
$\mathrm{~K}_{2}$ & 0,152 \\
$\mathrm{SO}_{3}$ & 0,146 \\
$\mathrm{P}_{2} \mathrm{O}_{5}$ & 0,297 \\
$\mathrm{ZnO}$ & 0,0046 \\
\hline
\end{tabular}


Tabel 4. Perbandingan karakteristik $\mathrm{CaO} / \mathrm{SiO}_{2}$ sebagai katalis pada pembuatan biodiesel dari beberapa hasil penelitian

Table 4. Comparison of $\mathrm{CaO} / \mathrm{SiO}_{2}$ characteristics as catalyst in biodiesel manufacturing from several research results

\begin{tabular}{|c|c|c|c|c|c|c|}
\hline \multirow{3}{*}{$\begin{array}{l}\text { Karakteristik permukaan } \\
\text { (Surface characteristics) }\end{array}$} & \multirow{3}{*}{$\begin{array}{l}\text { Penelitian ini } \\
\text { (This study) }\end{array}$} & \multicolumn{5}{|c|}{ Referensi (References) } \\
\hline & & Haryono, et al. & \multicolumn{2}{|c|}{ Lani et al.(2017) ${ }^{2)}$} & \multirow{2}{*}{$\begin{array}{l}\text { Correia et al., } \\
(2014)^{3)}\end{array}$} & \multirow{2}{*}{$\begin{array}{l}\text { Reyero, et al. } \\
(2014)^{4}\end{array}$} \\
\hline & & $(2018)^{1)}$ & (a) & (b) & & \\
\hline $\begin{array}{l}\text { Luas permukaan rata-rata } \\
\text { (Average specific surface area, } \mathrm{m}^{2} \mathrm{~g}^{-1} \text { ) }\end{array}$ & 30,0 & 16,2 & 12,3 & 6,83 & 1,60 & 6,0 \\
\hline $\begin{array}{l}\text { Volume pori total } \\
\text { (Total specific pore volume, } \mathrm{cm}^{3} \mathrm{~g}^{-1} \text { ) }\end{array}$ & 0,143 & 0,41 & 0,043 & 0,32 & 0,004 & - \\
\hline $\begin{array}{l}\text { Diameter pori rata-rata } \\
\text { (Average pore diameter, } \mathrm{nm} \text { ) }\end{array}$ & 4,52 & 4,23 & 11,76 & 7,86 & 11,44 & - \\
\hline $\begin{array}{l}\text { Densitas kebasaan } \\
\text { (Basic density, } \mathrm{mmol} \mathrm{OH}^{-1} \mathrm{~g}^{-1} \text { ) }\end{array}$ & 9,40 & - & - & - & - & 1,5 \\
\hline
\end{tabular}

Keterangan (Remarks): ${ }^{1)} \mathrm{CaO}$ dari kalsinasi cangkang telur diikuti pengecilan lanjut dengan planetary ball mill (CaO from calcined egg shells followed by further size reduction with planetary ball mill); ${ }^{2)}$ (a): CaO dari cangkang telur terkalsinasi yang diimpregnasikan pada permukaan $\mathrm{SiO}_{2}$ dari abu sekam padi ( $\mathrm{CaO}$ from calcined eggshells that impregnated on $\mathrm{SiO}_{2}$ surface from ash of rice husk); (b): $\mathrm{CaO}$ dari cangkang telur terkalsinasi pada $900^{\circ} \mathrm{C}$ selama 6 jam tanpa diimpregnasikan pada permukaan $\mathrm{SiO}_{2}$ padi $(\mathrm{CaO}$ from calcined egg shells at $900^{\circ} \mathrm{C}$ and 6 hours without impregnated on $\mathrm{SiO}_{2}$ surface); ${ }^{3)} \mathrm{CaO}$ dari kalsinasi cangkang telur pada suhu $900^{\circ} \mathrm{C}$ selama $2 \mathrm{jam}\left(\mathrm{CaO}\right.$ from calcination of egg shells at $90^{\circ} \mathrm{C}$ and 2 hours); ${ }^{4)} \mathrm{CaO}$ dengan kemurnian 99,9\% dari Sigma-Aldrich setelah disimpan selama 1 tahun ( $\mathrm{CaO}$ with 99.9\% purity from Sigma-Aldrich after one yaer storage).

penyangga $\mathrm{SiO}_{2}$ melalui metode impregnasi telah terbukti memperbaiki karakteristik permukaan $\mathrm{CaO}$ (Lani, Ngadi, Yahya, \& Rahman, 2017), begitu juga pada penelitian ini. Namun $\mathrm{CaO}$ tanpa diimpregnasikan pada $\mathrm{SiO}_{2}$ dimungkinkan memiliki luas permukaan spesifik lebih besar, jika terhadap $\mathrm{CaO}$ hasil dekomposisi termal dilakukan pengecilan lanjut (Haryono, Natanael, Rukiah, \& Yuliyati, 2018). Karakteristik dari katalis berbasis $\mathrm{CaO}$ tersebut pada akhirnya akan mempengaruhi aktivitas dan selektivitas dari katalis. Aktivitas dan selektivitas katalis salah satunya berkaitan erat dengan sifat-sifat fisik katalis, yaitu: ukuran partikeldan distribusiukurannya, luas permukaan, diameter pori dan distribusinya, morfologi, dan struktur katalis (Deutschmann, Knozinger, Kochloefl, \& Turek, 2009).

Kadar ALB dari minyak kemiri sunan setelah mengalami tahap esterifikasi pada berbagai variasi waktu dan tanpa esterifikasi ditampilkan pada Gambar 2. Kadar ALB dari minyak kemiri sunan pada tiap perlakuan waktu esterifikasi,

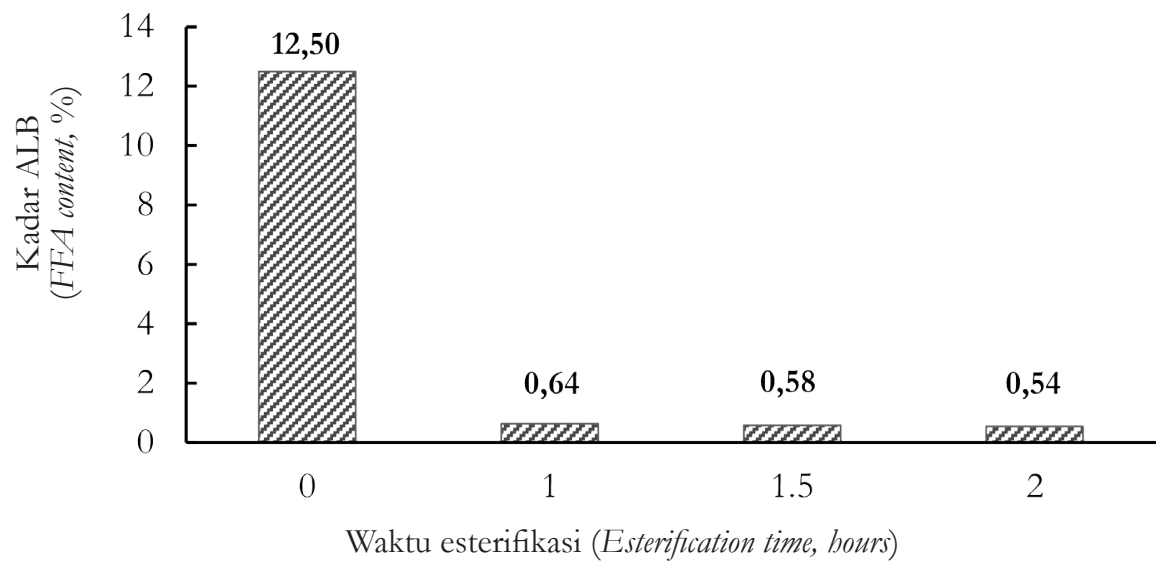

Gambar 2. Kadar asam lemak bebas dari minyak kemiri sunan pada berbagai variasi waktu esterifikasi

Figure 2. Free fatty acid content of kemiri sunan oil at various esterification times 
Tabel 5. Perbandingan rendemen, densitas, dan viskositas biodiesel dari minyak kemiri sunan dengan berbagai variasi kadar Asam Lemak Bebas (ALB)

Table 5. Comparison of yield, density, and viscosity of biodiesel from kemiri sunan oil with varied Free Fatty Acid (FFA) content

\begin{tabular}{|c|c|c|c|c|}
\hline \multicolumn{2}{|c|}{$\begin{array}{c}\text { Minyak kemiri sunan umpan } \\
\text { (Kemiri sunan oil feedstock) }\end{array}$} & \multicolumn{3}{|c|}{$\begin{array}{l}\text { Produk biodiesel } \\
\text { (Biodiesel products) }\end{array}$} \\
\hline $\begin{array}{l}\text { Sumber } \\
\text { (Sources) }\end{array}$ & $\begin{array}{c}\text { Kadar ALB } \\
\text { (FFA Content, \%) }\end{array}$ & $\begin{array}{c}\text { Rendemen } \\
\text { (Yield, \%) }\end{array}$ & $\begin{array}{c}\text { Densitas } \\
\left(\text { Density, } \mathrm{kg} \mathrm{m}^{-3}\right) \\
\end{array}$ & $\begin{array}{c}\text { Viskositas } \\
(\text { Viscosity, } c S t)\end{array}$ \\
\hline $\begin{array}{l}\text { Tanpa esterifikasi } \\
\text { (Without esterification) }\end{array}$ & 12,50 & 0,0 & - & - \\
\hline $\begin{array}{l}\text { Esterifikasi selama } 1 \mathrm{jam} \\
\text { (Esterification for } 1 \text { b) }\end{array}$ & 0,65 & 79,16 & 890 & 2,56 \\
\hline $\begin{array}{l}\text { Esterifikasi } 1,5 \text { jam } \\
\text { (Esterification for } 1.5 \text { h) }\end{array}$ & 0,58 & 81,28 & 890 & 2,52 \\
\hline \multirow[t]{2}{*}{$\begin{array}{l}\text { Esterifikasi } 2 \text { jam } \\
\text { (Esterification for } 2 \text { h) }\end{array}$} & 0,54 & 86,70 & 880 & 2,49 \\
\hline & & SNI 7182-2015 & $850-890$ & $2,3-6,0$ \\
\hline
\end{tabular}

seperti ditunjukkan pada Gambar 2, mengalami penurunan signifikan setelah satu jam reaksi jika dibandingkan dengan kadar ALB minyak kemiri sunan awal. Setelah satu jam esterifikasi, kadar ALB mengalami penurunan dari $12,50 \%$ menjadi 0,64\%, atau turun sekitar 94,9\%. Penurunan kadar ALB tersebut mengindikasikan bahwa reaksi esterifikasi telah berhasil mengkonversi ALB menjadi ester. Saat esterifikasi diperlama menjadi 1,5 dan 2 jam, kadar ALB dari minyak kemiri sunan tidak menunjukkan penurunan yang signifikan. Untuk mengetahui bagaimana pengaruh kandungan ALB di dalam minyak kemiri sunan terhadap kinerja $\mathrm{CaO} / \mathrm{SiO}_{2}$ dalam mengkatalisasi reaksi trans-esterifikasi, setiap minyak kemiri sunan dengan kadar ALB bervariasi tersebut selanjutnya direaksikan dengan metanol pada rasio mol minyak/metanol 1:9, kadar katalis heterogen $3 \%$, suhu reaksi $60^{\circ} \mathrm{C}$, dan selama dua jam. Hasil pengujian katalis pada tahap transesterifikasi tersebut ditampilkan pada Tabel 5 .

Hasil penentuan kinerja katalis $\mathrm{CaO} / \mathrm{SiO}_{2}$, sesuai data pada Tabel 5, menunjukkan bahwa keberadaan ALB di dalam minyak kemiri sunan sebagai umpan, berpengaruh terhadap aktivitas katalitik $\mathrm{CaO} / \mathrm{SiO}_{2}$. Setiap jenis minyak nabati tersusun dari beragam jenis asam lemak dengan kadar bervariasi (Dauqan \& Sani, 2011). Minyak nabati akan mengalami perubahan sifat fisiko-kimia selama tahap pemrosesan mulai dari pemanenan, ekstraksi minyak, dan penyimpanannya sampai tahap sintesis biodiesel
((Almeida, Viana, Costa, Silva, \& Feitosa, 2019); (Dawodu, Olutona, \& Obimakinde, 2015)). Hasil penelitian menunjukkan bahwa semakin sedikit kadar ALB terkandung di dalam minyak, kinerja katalis $\mathrm{CaO} / \mathrm{SiO}_{2}$ semakin meningkat. Hal tersebut ditunjukkan oleh semakin meningkatnya rendemen dan kualitas biodiesel yang dihasilkan (berdasarkan parameter densitas dan viskositas). Pada minyak kemiri sunan dengan kadar ALB terbanyak, yaitu $12,50 \%$, tahap trans-esterifikasi tidak mampu menghasilkan biodiesel. Fakta tersebut mengindikasikan antara trigliserida dari minyak kemiri sunan dan metanol tidak terjadi reaksi. Hal tersebut diduga sebagai akibat sebagian besar $\mathrm{CaO}$ yang berperan sebagai spesi aktif katalis telah bereaksi dengan ALB minyak kemiri sunan melalui reaksi netralisasi. ALB dapat menetralkan sisi basa dari $\mathrm{CaO}$ sehingga aktivitas katalitik dari $\mathrm{CaO}$ berkurang. Pernyataan tersebut didasarkan pada terdeteksinya puncak-puncak gugus karboksilat dari ALB jenis asam oleat pada spektrum FTIR dari katalis bekas (spent catalyst) basa heterogen berbasis Ca di bilangan gelombang 1703, 1280, dan $930 \mathrm{~cm}^{-1}$ (Yan et al., 2009). Di lain pihak, minyak kemiri sunan dengan kadar ALB terendah $(0,54 \%)$ menghasilkan biodiesel dengan rendemen tertinggi dan kualitas paling sesuai dengan SNI 7182-2015.

Peningkatan rendemen biodiesel seiring dengan semakin sesuainya parameter kualitas (densitas dan viskositas) biodiesel dengan SNI 7182-2015 merupakan pengkonfirmasian 
Tabel 6. Perbandingan kualitas biodiesel dari minyak kemiri sunan dengan katalis $\mathrm{CaO} /$ $\mathrm{SiO}_{2}$ dengan SNI 7182-2015 tentang biodiesel

Table 6. Comparation of biodiesel quality from kemiri sunan oil with $\mathrm{CaO} / \mathrm{SiO}_{2}$ catalyst to SNI 7182-2015 on biodiesel

\begin{tabular}{clccc}
\hline No. & \multicolumn{1}{c}{$\begin{array}{c}\text { Parameter } \\
\text { (Parameters) }\end{array}$} & $\begin{array}{c}\text { Satuan } \\
(\text { Unit })\end{array}$ & $\begin{array}{c}\text { Nilai } \\
(\text { Values })\end{array}$ & $\begin{array}{c}\text { SNI 7182-2015: } \\
\text { Biodiesel }\end{array}$ \\
\hline 1. & Densitas pada $40^{\circ} \mathrm{C}$ (Density) & $\mathrm{kg} / \mathrm{m}^{3}$ & 880 & $850-890$ \\
2. & Viskositas pada $40^{\circ} \mathrm{C}$ (Viscosity) & $\mathrm{cSt}$ & 2,49 & $2,3-6,0$ \\
3. & Kadar air (Moisture content) & $\%$ & 0,05 & $\max .0,05$ \\
4. & Bilangan asam (Acid number) & $\mathrm{mg} \mathrm{KOH} / \mathrm{g}$ & 0,89 & $\operatorname{max.} 0,60$ \\
5. & Bilangan iodin (Iodine number) & $\%$ & 66,08 & $\operatorname{max.~} 115$ \\
6. & Bilangan cetana (Cetane number) & - & $66,28^{\text {a) }}$ & $\min .51,0$ \\
\hline
\end{tabular}

Keterangan (Remarks): ${ }^{a}$ Dihitung sebagai fungsi bilangan penyabunan (SN) dan bilangan iodin (IN) menurut persamaan: $\mathrm{CN}=46,3+5458 / \mathrm{SN}-0,225 \mathrm{IN}$ (Azam, Waris, \& Nahar, 2005) (Calculated as a function of saponification and iodine number proposed by (Azam et al., 2005))

bahwa aktivitas katalitik $\mathrm{CaO}$ dalam reaksi pembentukan biodiesel semakin meningkat. Rendemen biodiesel dari minyak kemiri sunan dengan katalis heterogen padat $\mathrm{CaO} / \mathrm{SiO}_{2}$ pada penelitian ini relatif sama jika dibandingkan dengan penggunaan katalis basa homogen $\mathrm{KOH}$ (Hendra, 2014). Namun, penggunaan katalis $\mathrm{KOH}$ tersebut memberikan hasil biodiesel yang secara kualitas lebih rendah berdasarkan parameter densitas dan viskositas. Supriyadi et al. (2018) memperoleh biodiesel dari minyak kemiri sunan dengan rendemen 98,5\% ketika reaksi trans-esterifikasi dengan katalis $\mathrm{KOH}$ dilakukan dengan bantuan gelombang ultrasonik.

Pada penelitian ini, minyak kemiri sunan dengan kadar ALB 0,54\% ditetapkan sebagai minyak dengan kualitas terbaik untuk diproses lanjut ke tahap trans-esterifikasi. Untuk lebih memperkuat kesimpulan ini, terhadap biodiesel yang dihasilkan dari minyak kemiri sunan tersebut dilakukan analisis sifat fisiko-kimia lebih lanjut, meliputi: bilangan cetana, bilangan asam, kadar air, dan bilangan iodium. Hasil analisis sifat fisiko-kimia terhadap biodiesel selanjutnya dibandingkan dengan SNI 7182-2015 (Tabel 6). Mutu biodiesel yang dihasilkan pada penelitian ini secara umum sudah memenuhi SNI biodiesel, kecuali bilangan asam. Kadar ALB minyak kemiri sunan sebagai umpan tahap trans-esterifikasi diketahui sebesar 0,54\%. Kadar ALB minyak kemiri sunan tersebut jika dikonversikan menjadi bilangan asam kira-kira sekitar 1,08 mg KOH/g. Sementara itu, dari hasil analisis bilangan asam terhadap biodiesel diperoleh sebesar $0,89 \mathrm{mg}$ $\mathrm{KOH} / g$. Dengan demikian, selama reaksi transesterifikasi, kadar ALB mengalami penurunan sekitar $17,6 \%$.

Penurunan kadar ALB minyak kemiri sunan selama reaksi trans-esterifikasi tersebut menunjukkan bahwa katalis $\mathrm{CaO} / \mathrm{SiO}_{2}$ memiliki kemampuan dalam mengkatalisasi reaksi esterifikasi (pengkonversian ALB menjadi metil ester atau biodiesel), disamping peran utamanya dalam membantu pengkonversian minyak (trigliserida) menjadi biodiesel. Bilangan asam yang lebih tinggi dibandingkan SNI biodiesel dapat diatasi salah satunya melalui penurunan lebih lanjut kadar ALB minyak kemiri sunan sebelum tahap trans-esterifikasi. Keberadaan ALB melebihi toleransi akan berpotensi menyebabkan terjadinya reaksi penyabunan antara ALB dengan $\mathrm{CaO}$ sehingga aktivitas katalisis $\mathrm{CaO}$ mengalami penurunan sampai pada tingkat tertentu. Penurunan aktivitas katalis $\mathrm{CaO}$ tersebut juga dilaporkan oleh Haruna, Fatima, dan Ndam (2015) pada pengkonversian minyak jarak pagar menjadi biodiesel, dimana minyak jarak pagar dengan kadar ALB 7,8\% menghasilkan rendemen biodiesel sebanyak $87,49 \%$, dan kemudian rendemen biodiesel mengalami penurunan menjadi $84,42 \%$ ketika digunakan minyak jarak pagar dengan kadar ALB 8,16\%. 


\section{KESIMPULAN}

\section{A. Kesimpulan}

Katalis $\mathrm{SiO}_{2}$ terimpregnasi $\mathrm{CaO}$ telah berhasil disintesis dari bahan alam berupa cangkang telur dan sekam padi. Katalis $\mathrm{CaO} / \mathrm{SiO}_{2}$ memiliki aktivitas katalitik pada reaksi trans-esterifikasi untuk mengkonversi minyak kemiri sunan menjadi biodiesel. Pada kondisi reaksi transesterifikasi yang diujikan, kinerja katalis $\mathrm{CaO} /$ $\mathrm{SiO}_{2}$ tersebut dipengaruhi oleh kadar ALB dari minyak kemiri sunan umpan. Semakin rendah kadar ALB dalam minyak kemiri sunan, rendemen dan mutu biodiesel yang dihasilkan mengalami peningkatan. Biodiesel dari minyak kemiri sunan yang disintesis dengan bantuan katalis $\mathrm{SiO}_{2}$ terimpregansi $\mathrm{CaO}$ pada kondisi optimum di tahap trans-esterifikasi telah memenuhi standar kualitas biodiesel menurut SNI biodiesel 71822015 untuk parameter densitas, viskositas, kadar air, bilangan iodin, dan bilangan cetana.

\section{B. Saran}

Perlu dilakukan pengkajian lanjut untuk lebih menurunkan bilangan asam dari biodiesel minyak kemiri sunan melalui metode lainnya seperti optimasi tahap esterifikasi, optimasi lanjut tahap trans-esterifikasi (mengkaji pengaruh kadar katalis, rasio mol minyak/metanol, dan lama reaksi), dan melakukan perbaikan karakteristik katalis $\mathrm{CaO} / \mathrm{SiO}_{2}$.

\section{KONTRIBUSI PENULIS}

Ide, desain dan rancangan percobaan dilakukan oleh HR, YY, SN. Pengambilan data dilakukan oleh MR, HR. Analisis data dilakukan oleh HR, YY, MR, ARN dan penulisan manuskrip dilakukan oleh HR, ARN, YY. Perbaikan dan finalisasi manuskrip dilakukan oleh HR, ARN, SN.

\section{DAFTAR PUSTAKA}

Almeida, D. T. de, Viana, T. V., Costa, M. M., Silva, C. de S., \& Feitosa, S. (2019). Effects of different storage conditions on the oxidative stability of crude and refined palm oil, olein and stearin (Elaeis guineensis). Food Science and Technology, 39(suppl 1), 211217. doi: $10.1590 /$ fst. 43317.

Azam, M. M., Waris, A., \& Nahar, N. M. (2005). Prospects and potential of fatty acid methyl esters of some non-traditional seed oils for use as biodiesel in India. Biomass and Bioenergy, 29(4), 293-302. doi: 10.1016/j. biombioe.2005.05.001.

Banković-Ilić, I. B., Miladinović, M. R., Stamenković, O. S., \& Veljković, V.B. (2017). Application of nano CaO-based catalysts in biodiesel synthesis. Renewable and Sustainable Energy Reviews, 72(December 2018), 746760. doi: 10.1016/j.rser.2017.01.076.

Correia,L.M., Saboya, R. M.A., deSousa Campelo, N., Cecilia, J. A., Rodríguez-Castellón, E., Cavalcante, C. L., \& Vieira, R. S. (2014). Characterization of calcium oxide catalysts from natural sources and their application in the transesterification of sunflower oil. Bioresource Technology, 151, 207-213. doi: 10.1016/j. biortech.2013.10.046.

Dauqan, E., \& Sani, H. (2011). Fatty acids composition of four different vegetable oils (red palm olein, palm olein, corn oil and coconut oil) by gas chromatography. International Conference on Chemistry Engineering, 14, 31-34. doi: 10.4236/ fns.2011.24036.

Dawodu, M. O., Olutona, G. O., \& Obimakinde, S. O. (2015). Effect of temperature on the chemical characteristics of vegetable oils consumed in Ibadan, Nigeria. Pakistan Journal of Nutrition, 14(10), 698-707. doi: 10.3923/pjn. 2015.698.707. 
Deutschmann, O., Knozinger, H., Kochloefl, K., \& Turek, T. (2009). Heterogeneous catalysis and solid catalyst. Weinheim-Germany: WileyVCH Verlag GmbH \& Co.

Djenar, N.S., \& Lintang, N. (2012). Esterifikasi minyak kemiri sunan (Aleurites trisperma) dalam pembuatan biodiesel. Bionatura-Jurnal Ilmu Hayati dan Fisik, 14(3), 229-235.

Ghorbani, F., Sanati, A. M., \& Maleki, M. (2015). Production of silica nanoparticles from rice husk as agricultural waste by environmental friendly technique. Environmental Studies of Persian Gulf, 2(1), 56-65.

Habibie, S., \& Clarke, S. (2012). The current status and future development of biodiesel in Indonesia. Jurnal Sains dan Teknologi Indonesia, 14(1), 62-73.

Haruna, I., Fatima, M., \& Ndam, V. (2015). Effect of high free fatty acid feedstock on methyl esters yield using bulk calcium oxide catalyst. International Journal of Scientific \& Technology Research, 4(3), 186-189.

Haryono, Natanael, C. L., Rukiah, \& Yuliyati, Y. B. (2018). Kalsium oksida mikropartikel dari cangkang telur sebagai katalis pada sintesis biodiesel dari minyak goreng bekas. Jurnal Material Dan Energi Indonesia, 8(1), 8-15.

Hendra, D. (2014). Pembuatan biodiesel dari biji kemiri sunan. Jurnal Penelitian Hasil Hutan, 32(1), 37-45.

Juan, J. C., D.A., K., Wu, T., \& Taufiq. (2011). Biodiesel production from jatropha oil by catalytic and non-catalytic approaches: an overview. Bioresource Technology, 2(102), 452-460.

Kim, M., Salley, S. O., \& Ng, K. Y. S. (2008). Transesterification of glycerides using a heterogeneous resin catalyst combined with a homogeneous catalyst. Energy and Fuels, 22(6), 3594-3599. doi: 10.1021/ ef800443x.

Knothe, G., Gerpen, J. V., \& Krahl, J. (2005). The biodiesel handbook. Champaign-Illinois: : AOCS Press.
Kramadibrata, A. M., Muhaemin, M., Nurjanah, S., Mardawati, E., Daradjat, W., Hendarto, \& Rosalinda, S. (2017). Rekayasa proses produksi biodiesel dan aplikasinya pada engine termodifikasi. Laporan Academic Leadership Grant. Universitas Padjadjaran, Bandung.

Lani, N. S., Ngadi, N., Yahya, N. Y., \& Rahman, R. A. (2017). Synthesis, characterization and performance of silica impregnated calcium oxide as heterogeneous catalyst in biodiesel production. Journal of Cleaner Production, 146, 116-124. doi: 10.1016/j. jclepro.2016.06.058.

Le, N.T.H., \& Jeong, H. . (2014). Synthesis and characterization of uniform silica nanoparticles on nickel substrate by spin coating and sol-gel method. Chemical Physics Letters, 349-354.

Loy, C. W., Matori, K. A., Lim, W. F., Schmid, S., Zainuddin, N., Wahab, Z. A., ... \& Zaid, M. H. M. (2016). Effects of calcination on the crystallography and nonbiogenic aragonite formation of ark clam shell under ambient condition. Advances in Materials Science and Engineering, 1(1). doi: 10.1155/2016/2914368.

Mancini, A., Imperlini, E., Nigro, E., Montagnese, C., Daniele, A., Orrù, S., \& Buono, P. (2015). Biological and nutritional properties of palm oil and palmitic acid: Effects on health. Molecules, 20(9), 17339-17361. doi: 10.3390/molecules 200917339.

Maneerung, T., Kawi, S., Dai, Y., \& Wang, C.-H. (2016). Sustainable biodiesel production via transesterification of waste cooking oil by using $\mathrm{CaO}$ catalysts prepared from chicken manure. Energy Conversion and Management, (123), 487-497.

Mat, R., Samsudin, R. A., Mohamed, M., \& Johari, A. (2012). Solid catalysts and their application in biodiesel production. Bulletin of Chemical Reaction Engineering and Catalysis, 7(2), 142-149. doi: 10.9767/ bcrec.7.2.3047.142-149. 
Murugesan, A., Umarani, C., Subramanian, R., \& Nedunchezhian, N. (2009). Biodiesel as an alternative fuel for diesel engines-A review. Renewable and Sustainable Energy Reviews, 3(13), 653-662.

Nurjanah, S., Kramadibrata, A. M., Muhaemin, M., Handarto, Herwanto, T., Saukat, M., ... Haryono. (2019). Study on different capacity of transesterification process in biodiesel production from kemiri sunan (Reutalis trisperma). IOP Conference Series.: Earth Environmental Science, 1-10.

Pranowo, D., Syakir, M., Prastowo, B., Herman, M., Aunillah, A., \& Sumanto. (2013). Pembuatan biodiesel dari kemiri sunan (Reutealis trisperma (Blanco) Airy Shaw) dan pemanfaatan hasil samping. Jakarta: IAARD Press.

Reyero, I., Arzamendi, G., \& Gandía, L. M. (2014). Heterogenization of the biodiesel synthesis catalysis: $\mathrm{CaO}$ and novel calcium compounds as transesterification catalysts. Chemical Engineering Research and Design, 92(8), 1519-1530. doi: 10.1016/j. cherd.2013.11.017.

Sanford, S., White, J., \& Shah, P. (2009). Feedstock and biodiesel characteristics report. Renewable Energy Group Inc., 1-136. Diunduh dari http://www.biodiesel.org/ reports/20091117_gen-398.pdf, pada 10 Oktober 2019.

Standar Nasional Indonesia (SNI). (2015). Biodiesel (SNI 7182:2015). Badan Standardisasi Nasional, Jakarta.
Supriyadi, S., Purwanto, P., Anggoro, D. D., \& Hermawan. (2018). Enhancing biodiesel from kemiri sunan oil manufacturing using ultrasonics. E3S Web of Conferences, 31, 1-5. doi: 10.1051/e3sconf/20183102014.

Tangboriboon, N., Kunanuruksapong, R., \& Sirivat, A. (2012). Preparation and properties of calcium oxide from eggshells via calcination. Materials Science- Poland, 30(4), 313-322. doi: 10.2478/s13536-0120055-7.

Witoon, T., Bumrungsalee, S., Vathavanichukul, P., Palitsakun, S., Saisriyoot, M., Faungnawakij, K. (2014). Biodiesel production from transesterification of palm oil with methanol over $\mathrm{CaO}$ supported on bimodal meso-macroporous silica catalyst. Bioresource Technology, (156), 329-334. doi: 10.1016/j.biortech.2014.01.076.

Yamaguchi, N., Masuda, Y., Yamada, Y., Narusawa, H., Han-Cheol, C., Tamaki, Y., \& Miyazaki, T. (2015). Synthesis of CaO$\mathrm{SiO}$ compounds using materials extracted from industrial wastes. Open Journal of Inorganic Non-Metallic Materials, 05(01), 1-10. doi: 10.4236/ojinm.2015.51001.

Yan, S., Kim, M., Salley, S. O., \& Simon, K. Y. (2009). Oil transesterification over calcium oxides modified with lanthanum. Applied Catalysis A: General, 360(2), 163-170. doi: 10.1016/j.apcata. 2009.03.015. 
